\title{
DEFORMATION BEHAVIOUR OF A NATURAL-SHAPED BONE SCAFFOLD
}

\author{
OBNAŠANJE NARAVNO OBLIKOVANEGA OGRODJA KOSTI PRI \\ DEFORMACIJI
}

\author{
Daniel Kytýřr ${ }^{1,2}$, Tomáš Doktor ${ }^{1,2}$, Ondřej Jiroušek¹, Tomáš Fíla ${ }^{1,2}$, \\ Petr Koudelka ${ }^{1,2}$, Petr Zlámal ${ }^{2}$ \\ 1Czech Technical University in Prague, Faculty of Transportation Sciences, Department of Mechanics and Materials, Konviktská 20, \\ 11000 Prague 1, Czech Republic \\ 2Institute of Theoretical and Applied Mechanics, v.v.i., Academy of Sciences of the Czech Republic, Prosecká 76,19000 Prague 9 , \\ Czech Republic \\ kytyr@fd.cvut.cz
}

Prejem rokopisa - received: 2014-08-11; sprejem za objavo - accepted for publication: 2015-05-07

\author{
doi: $10.17222 / \mathrm{mit} .2014 .190$
}

\begin{abstract}
The study aims at mechanical testing of an artificial bone structure in the form of a scaffold for the application in the repairs of trabecular bones after wounds or degenerative diseases. Such artificial construct has to conform to many requirements including biocompatibility, permeability properties and bone-integration characteristics. Recently, self-degradable bone scaffolds suitable for natural-bone-tissue ingrowth optimized with respect to mechanical properties and body-fluid flow have been considered as an alternative to allografts and autografts. Here, an analysis of deformation behaviour of a scaffold with a morphology identical to the natural bone is the first step in this task. In this work, the geometry and morphology of scaffold specimens produced with direct 3D printing were based on a 3D model derived from the X-ray-computed micro-tomography measurement of a real trabecular bone. The geometrical model was upscaled four times in order to achieve the optimum ratio between its resolution and the resolution of the 3D printer. For its biocompatibility and self-degradability, polylactic acid was used as the printing material. The mechanical characteristics were obtained from a series of uniaxial compression tests, with an optical evaluation of the strain field on the surfaces of the specimens. The acquired stress-strain curves were compared with the characteristics of a real trabecular bone obtained with time-lapse microtomography measurements, evaluated with the digital volumetric correlation method. The results show good correspondence of the stiffness values for both the natural and artificial bone specimens.

Keywords: bone scaffold, polylactic acid, additive manufacturing, compression loading, microtomography
\end{abstract}

Namen študije je mehansko preizkušanje umetnega ogrodja kosti za obnovo trabekularnih kosti po poškodbah ali degenerativnih boleznih. Tako umetno ogrodje mora ustrezati mnogim zahtevam, kot so biokompatibilnost, prepustnost in možnost vraščanja kostnega tkiva. Samo razgradljivo ogrodje kosti, primerno za naravno vraščanje kostnega tkiva, optimirano glede na mehanske lastnosti in toka telesnih tekočin, je bilo proučevano kot nadomestek za presajanje tujega ali lastnega tkiva. Prvi korak pri tej nalogi je analiza obnašanja ogrodja, z morfologijo podobno naravni kosti. V tem delu je bila geometrija in morfologija vzorčnega ogrodja izdelana $\mathrm{z}$ neposrednim tridimenzionalnim tiskanjem, na osnovi tridimenzionalnega modela, dobljenega $\mathrm{z}$ meritvami s pomočjo rentgenske tomografije realne trabekularne kosti. Geometrijski model je bil povečan štirikrat, da bi dobili optimalno razmerje med njegovo resolucijo in resolucijo tridimenzionalnega tiskalnika. Za biokompatibilnost in sâmo razgradljivost, je bila za tiskanje uporabljena polilaktična kislina. Mehanske značilnosti so bile dobljene $\mathrm{z}$ vrsto enoosnih tlačnih preizkusov in $\mathrm{z}$ optično oceno napetostnega polja na površini vzorcev. Pridobljene krivulje napetost-raztezek so bile primerjane z značilnostmi realne trabekularne kosti, ki so bile dobljene z zaporednimi mikrotomografskimi meritvami in ocenjene z digitalno volumetrično metodo korelacije. Rezultati kažejo dobro ujemanje togosti obeh vzorcev, tako naravne kot umetne kosti.

Ključne besede: ogrodje kosti, polilaktična kislina, tridimenzionalnega tiskanje, tlačno obremenjevanje, mikrotomografija

\section{INTRODUCTION}

The change in the lifestyle during the past decades (the so-called modern lifestyle characteristic caused by a lack of sufficient physical activities coupled with an improper type of nutrition) coupled with an increasing life expectancy in many countries caused a significant increase in health-care costs. Globally more than $30 \%$ of women and $20 \%$ of men in elderly age suffer from bone disorders. The increase is expected to double by $2020,{ }^{1}$ partially also due to an increased occurrence of obesity. Here, bone-tissue engineering and specifically designed implants with functionally graded properties represent a modern approach to the bone-repair process ${ }^{2}$ with the goal to create an implant that is anatomically and functionally compatible with the surrounding tissue. ${ }^{3}$ In the recent orthopaedic practice, repairs of defective bones have been most commonly carried out using autografts and allografts. Although used for many years, natural grafts possess several limitations and potentials for complications due to various influences including the donor-site morbidity, a loss of bone inductive factors, resorption during healing, anatomical variations, etc. ${ }^{4}$ To overcome these problems, implants in the form of an artificial bone represent an attractive alternative with a significant, though not yet fully exploited potential. In order to engineer such a synthetic scaffold with optimum characteristics, several factors and parameters have to be taken into account. ${ }^{5}$ Among such factors, the type of the cancellous bone, mechanical properties, the geometry ${ }^{6}$ 
and the expected transport phenomena ${ }^{7}$ are the most important for the design of a synthetic porous bone. Thus, with respect to the selected application (i.e., the location within the skeletal microarchitecture $)^{8}$ stiffness and permeability properties have to be properly selected to precisely match the properties of the natural cancellous bone. Identification of the trabecular microstructure and comparison of deformation behaviour of the natural bone with the synthetic replication is the first step in the artificial-bone-structure optimization. A combination of radiological imaging methods and additive manufacturing was used for preparing a natural-shaped bone scaffold. A set of uniaxial compression tests were performed to obtain the scaffold loading response represented by stress-strain diagrams. The strain calculation was based on image-registration techniques, digital image correlation (DIC) for optical data and digital volume correlation (DVC) for tomographic data.

\section{MATERIALS AND METHODS}

\subsection{Natural bone sample}

Trabecular bone tissue is a biological material consisting of basic structural elements called trabeculae. Individual trabeculae are joined into a network with a high porosity (50-90\%) naturally adapted to distribute and dissipate the energy from external loads. For the purpose of this study, original natural bone samples were prepared by drilling them from the caput femoris of 42-year and 72-year-old male donors. The samples with a diameter of $5 \mathrm{~mm}$ and a height of approximately 10 $\mathrm{mm}$ were put into an ultrasonic bath to remove the remaining bone marrow. Formaldehyde solution was used to avoid biological degradation and to ensure sample preservation. The upper and bottom parts of the samples were embedded in a 2-component epoxy resin and after the hardening, two plan-parallel baseplates were cut with a precise saw. This preparation procedure minimises the risk of a rapid collapse of the bone

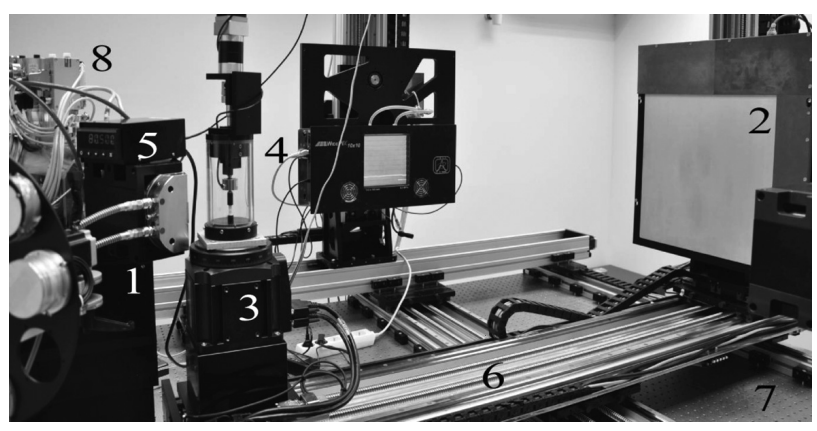

Figure 1: Microtomography set-up: 1) X-ray source, 2) detector, 3) rotary stage, 4) loading device, 5) load-cell controller, 6) linear stage, 7) anti-vibration table and 8) cooling

Slika 1: Naprava za mikrotomografijo: 1) vir rentgenskih žarkov, 2) detektor, 3) nosilec za rotiranje, 4) naprava za obremenjevanje, 5) nadzor pri obremenjevanju, 6) linearni nosilec, 7) antivibracijska mizica in 8) hlajenje samples under loading due to a crack damage of the microstructure.

\subsection{Microtomography measurement}

In order to acquire a geometrically precise model of the internal trabecular structure, a custom-designed microtomography device (Figure 1) was employed. The irradiation of the sample was performed using a microfocus $\mathrm{X}$-ray tube with a high-resolution transmission target (XWT 160, X-Ray Worx, Germany). Radiograms were acquired using a large $(410 \mathrm{~mm} \times 410 \mathrm{~mm}) \mathrm{X}$-ray flat-panel scintillating detector (XRD 1622, PerkinElmer Inc., USA) with an effective resolution of 2048 pixels $\times$ 2048 pixels with a $200 \mu \mathrm{m}$ pitch. A custom-designed loading device composed of a stiff frame with a low absorption of X-rays was designed specially for the microtomography under loading. Force was gradually applied on the specimens using the translation stage (7T173-20, Standa Ltd., Lithuania) with a $2 \mu \mathrm{m}$ tracking accuracy and the applied force was measured using a small-scale force transducer (U9b, HBM, Germany) with a nominal capacity of $500 \mathrm{~N}$. Before the loading procedure, a sample was scanned in 720 projections (acquisition $2 \times 0.5 \mathrm{~s}$ ) with an angular step of $0.5^{\circ}$ to obtain a detailed geometrical model of the microstructure. Then a time-lapse tomography (tomography under loading) measurement was performed to obtain the information about the spatial strain distribution during the loading. ${ }^{9}$ The specimen was incrementally loaded with $1 \%$ increment up to the total deformation of $6 \%$. After each loading step, microtomography was performed to capture the deformed microstructure. Acquisitions with 180 projections at $2^{\circ}$ were used for this purpose to reduce the computational costs of the reconstruction procedure. The spatial strain distribution was assessed utilizing DVC, which is an extension of the image-registration techniques to three dimensions. ${ }^{10}$

Linearization of the attenuation range (a beamhardening correction) was applied to reduce the noise and improve the contrast of individual projections. ${ }^{11}$ Due to a high porosity of the samples and a small thickness of the trabeculae (approximately $200 \mu \mathrm{m}$ ), the cone-beam reconstruction algorithm ${ }^{12}$ was used to eliminate the distortion of the reconstructed data caused by the divergent nature of the X-ray beam.

\subsection{Polylactic acid}

Polylactic acid $\left(\mathrm{C}_{3} \mathrm{H}_{4} \mathrm{O}_{2}\right)_{\mathrm{n}}$ (PLA) is a biodegradable thermoplastic polyester derived from biomass and produced from the starch of various crop plants (e.g., corn, cereals, potatoes, etc.). The material properties of PLA are comparable with those of synthetic plastics, but they are achieved at significantly lower energetic requirements. ${ }^{13}$ PLA is highly biocompatible ${ }^{14}$ and suitable for the use in $3 \mathrm{D}$ printers making an attractive solution for endoprosthesis. 


\subsection{PLA bulk testing}

The production of the samples was carried out using a Profi3Dmaker (Aroja, Czech Republic) 3D printing device equipped with a $200 \mu \mathrm{m}$ printing nozzle, operated in the rapid additive-manufacturing mode with a slice resolution of $250 \mu \mathrm{m}$. The material properties of the PLA printer filament are not guaranteed by the producer and the influence of the printing process on the material characteristics is unknown; therefore, cylinder samples with dimensions of $20 \mathrm{~mm} \times 28 \mathrm{~mm}$ (diameter, height) were tested in different printing modes to choose the ideal printing set-up for the trabecular-bone replica manufacturing. The samples were produced at $100 \%, 70$ $\%$ and $50 \%$ filling levels. With all the filling levels, the products consisted of a $500 \mu \mathrm{m}$ shell and a core with a defined filling amount. In the case of a reduced filling amount, the core was created using a random-oriented fibre meshwork with a defined overall porosity. To verify the declared values of the filling level, the samples were weighed with a laboratory scale.

\subsection{Bone scaffold development}

The reconstructed tomographic-image data were subjected to the standard post-processing methods (including thresholding and identification of the connected components) using custom segmentation and modelling software to obtain binary spatial-image data without isolated fragments. Then the marching cube algorithm ${ }^{15}$ was used to extract the polygonal mesh of an isosurface from the three-dimensional scalar-image data (as depicted in Figure 2). Subsequently, this polygonal mesh was carefully smoothed and decimated in an iterative manner to obtain a surface suitable for 3D printing. Because of the technical parameters of the available 3D printer, the model was upscaled three times to ensure a proper geometry of the printed replica.

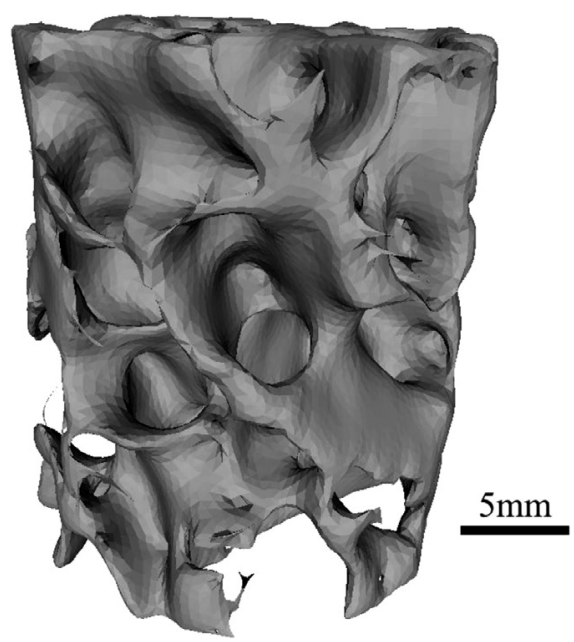

Figure 2: Model of trabecular-bone microstructure used for additive manufacturing

Slika 2: Model mikrostrukture trabekularne kosti, uporabljen pri tridimenzionalnem tiskanju

\subsection{Compression tests}

The compression test of both bulk and porous specimens was performed in a displacement-controlled loading mode using a custom-designed uniaxial loading device with a loading capacity of up to $2 \mathrm{kN}$. The load-bearing frame was designed as an open cylinder with expanded ends mounted on a stiff metallic plate manufactured from polyamide-imide thermoplastic. The displacement of the loading platens was controlled by stepper motor SX17-1705 (Microcon, Czech Republic) attached to a CPU 17A 100 harmonic drive (Harmonic Drive, USA) with a transmission ratio of $250: 1$ leading to an accuracy of displacement in the order of micrometers. High-accuracy load cell U9b (HBM, Germany) was connected to an OM 502T (Orbit Merret, Czech Republic) programmable indicator. The samples were loaded up to a $20 \%$ deformation at a constant loading rate of $20 \mu \mathrm{m} \mathrm{s}^{-1}$. Strains were derived from optically measured deformations, evaluated with the DIC algorithm. For this purpose, images of the loaded specimens were acquired with a high-resolution CCD camera (Manta G-504B, AVT, Germany) attached to telecentric zoom lens TCZR 072 (Opto Engineering, Italy). An in-house software based on the GNU/Linux real-time operation software and LinuxCNC open-source project was used to control the experiments. For the DIC procedure, a custom Matlab tool ${ }^{16}$ based on the Lucas-Kanade algorithm ${ }^{17}$ was used.

\section{RESULTS}

The material properties of bulk PLA were measured based on the compression tests of the PLA solid cylindrical samples at different levels of filling. Stress-strain curves obtained from the force record and optically measured strain are depicted in Figure 3. From the slope of the linear parts of the stress-strain diagrams, Young's moduli presented in Table $\mathbf{1}$ were estimated.

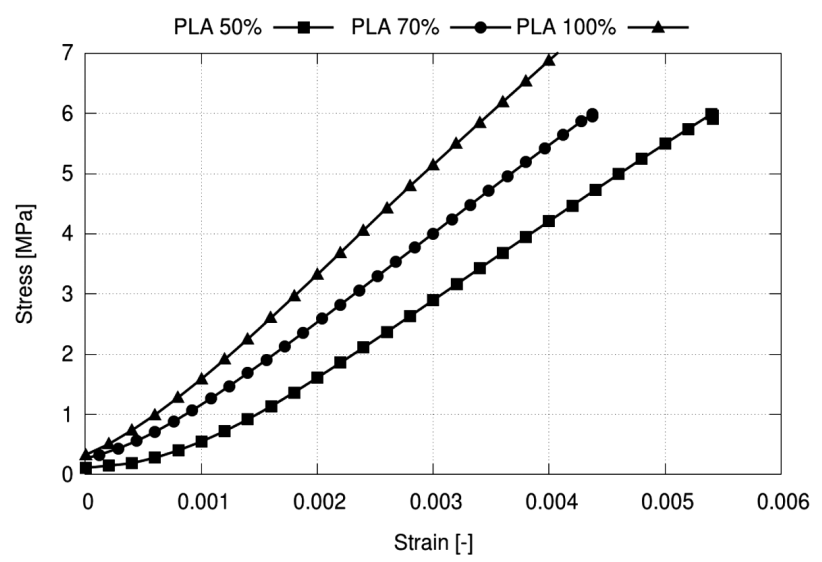

Figure 3: Stress-strain diagram of the PLA bulk material with different levels of filling

Slika 3: Obremenitveni diagram PLA materiala z različnimi stopnjami polnjenja 
Table 1: Properties of PLA used for additive manufacturing Tabela 1: Lastnosti PLA, ki se uporabljajo pri tridimenzionalnem tiskanju

\begin{tabular}{|c|c|c|c|}
\hline Sample & Filling $(\%)$ & Weight $(\mathrm{g})$ & $E(\mathrm{GPa})$ \\
\hline 1 & 100 & 15.300 & 2.396 \\
\hline 2 & 70 & 11.937 & 1.864 \\
\hline 3 & 50 & 9.160 & 1.380 \\
\hline
\end{tabular}

Because of a low PLA elastic modulus (compared to the bone tissue) and a rod- or shell-like shape of the replicated inner structure, the PLA scaffold was manufactured only in the full filling mode. Four identical PLA specimens representing the natural-bone-shaped upscaled scaffold were used for the compression test. For the optical measurement of the deformation of the complex sample surface, the data acquired from four different loading scenes (rotated by $90^{\circ}$ ) were evaluated. A sample collapsed after the compression test is depicted in Figure 4.

Deformation behaviour of the PLA models of the trabecular structure in comparison with the stress-strain curves of the natural bone structure is depicted in Figure 5. Good agreement between the elastic parts of both materials was observed. The sample with a natural bone volume fraction (bone volume/total volume $=25 \%$ ) exhibits a stiffness similar to the real-bone structure. Therefore, PLA is suitable for other bone-scaffold developments based on regular cells.

\section{CONCLUSION}

Compression tests of the natural-shaped additivemanufactured PLA samples of the trabecular-bone structure were performed to assess deformation behaviour of the homogenous solid phase of the synthetic material. The results will be used for designing an artificial bone structure with effective mechanical properties, close to the ones of a real, healthy bone. A low bone volume/total volume ratio of the real-bone structure provides a sufficient reserve for increasing the strength of the scaffold

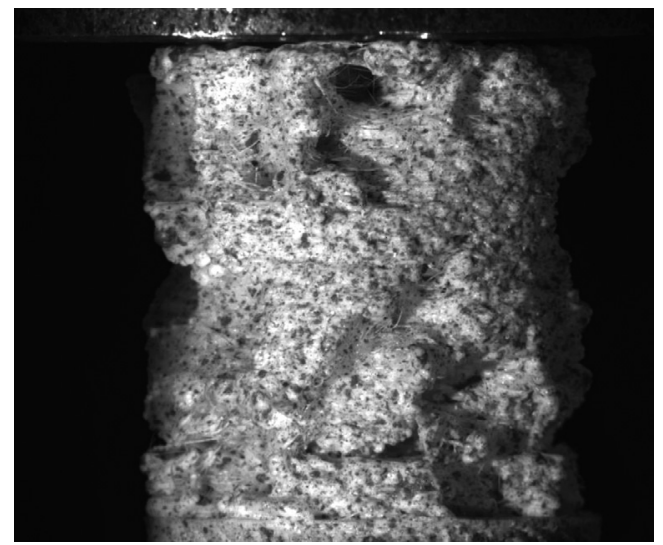

Figure 4: Example of a PLA scaffold collapsed after the compression test

Slika 4: Primer porušenega PLA kostnega ogrodja po tlačnem preizkusu

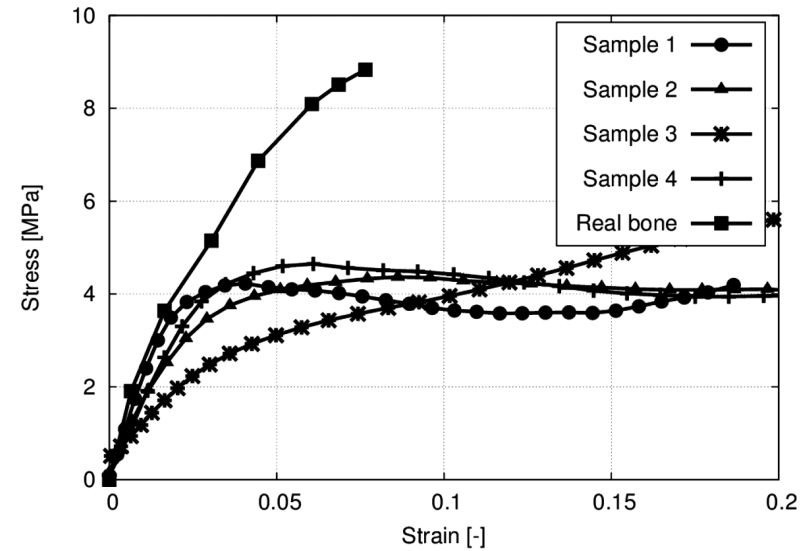

Figure 5: Stress-strain diagrams for the PLA-additive-manufactured and natural bone

Slika 5: Diagram napetost-raztezek za 3D tiskano in naravno kost

by increasing its relative density. A higher cross-section of the basic structure elements (which would still enable the tissue ingrowth) may reduce the required resolution of manufacturing devices. Additive manufacturing of biodegradable complex structures is a promising way for the bone-scaffold development. Based on these findings, the artificial bone structure used for the replacements of trabecular bones will be optimized with respect to structural, mechanical and permeability properties.

\section{Acknowledgements}

The research was supported by the Grant Agency of the Czech Technical University in Prague (grant No. SGS15/225/OHK2/3T/16) and by institutional support RVO: 68378297.

\section{REFERENCES}

${ }^{1}$ U.S. Department of Health and Human Services, Bone Health and Osteoporosis: A Report of the Surgeon General, Rockville 2004

${ }^{2}$ H. L. M. Bao, E. Y. Teo, M. S. K. Chong, Y. Liu, M. Choolani, J. K. Y. Chan, Advances in Bone Tissue Engineering, Regenerative Medicine and Tissue Engineering, InTech, Rijeka 2013, doi:10.5772/55916

${ }^{3}$ H. Razi, S. Checa, K. Schaser, G. N. Duda, Shaping scaffold structures in rapid manufacturing implants: A modeling approach toward mechano-biologically optimized configurations for large bone defect, Journal of Biomedical Materials Research, Part B: Applied Biomaterials, 100 (2012) 7, 1736-1745, doi:10.1002/jbm.b.32740

${ }^{4}$ A. R. Vaccaro, K. Chiba, J. G. Heller, T. C. Patel, J. S. Thalgott, E. Truumees, J. S. Fischgrund, M. R. Craig, S. C. Berta, J. C. Wang, Bone grafting alternatives in spinal surgery, Spine Journal, 2 (2002) 3, 206-215, doi:10.1016/S1529-9430(02)00180-8

${ }^{5}$ A. Gantar, L. P. Da Silva, J. M. Oliveira, A. P. Marques, V. M. Correlo, S. Novak, R. L. Reis, Nanoparticulate bioactive-glass-reinforced gellan-gum hydrogels for bone-tissue engineering, Materials Science and Engineering C, 43 (2014), 27-36, doi:10.1016/j.msec.2014. 06.045

${ }^{6}$ V. P. W. Shim, L. M. Yang, J. F. Liu, V. S. Lee, Characterisation of the dynamic compressive mechanical properties of cancellous bone from the human cervical spine, International Journal of Impact Engineering, 32 (2005) 1-4, 525-540, doi:10.1016/j.ijimpeng.2005. 03.006 


\section{KYTÝŘ et al.: DEFORMATION BEHAVIOUR OF A NATURAL-SHAPED BONE SCAFFOLD}

${ }^{7}$ S. S. Kohles, J. B. Roberts, M. L. Upton, C. G. Wilson, L. J. Bonassar, A. L. Schlichting, Direct perfusion measurements of cancellous bone anisotropic permeability, Journal of Biomechanics, 34 (2001) 9, 1197-1202, doi:10.1016/S0021-9290(01)00082-3

${ }^{8}$ E. F. Morgan, H. H. Bayraktar, T. M. Keavenyemail, Trabecular bone modulus-density relationships depend on anatomic site, Journal of Biomechanics, 36 (2003) 7, 897-904, doi:10.1016/S0021-9290 (03)00071-X

${ }^{9}$ O. Jirousek, P. Zlamal, D. Kytyr, M. Kroupa, Strain analysis of trabecular bone using time-resolved X-ray microtomography, Nuclear Instruments and Methods in Physics Research, Section A: Accelerators, Spectrometers, Detectors and Associated Equipment, 633 (2011) 1, 148-151, doi:10.1016/j.nima.2010.06.151

${ }^{10}$ O. Jirousek, I. Jandejsek, D. Vavrik, Evaluation of strain field in microstructures using micro-CT and digital volume correlation, Journal of Instrumentation, 6 (2011) 1, C01039, doi:10.1088/1748-0221/6/ 01/C01039

${ }^{11}$ D. Vavrik, J. Jakubek, Radiogram enhancement and linearization using the beam hardening correction method, Nuclear Instruments and Methods in Physics Research Section A: Accelerators, Spectrometers, Detectors and Associated Equipment, 607 (2009) 1, 212-214, doi:10.1016/j.nima.2009.03.156
${ }^{12}$ L. A. Feldkamp, L. C. Davis, J. W. Kress, Practical cone-beam algorithm, Journal of the Optical Society of America A, 1 (1984) 6, 612-619

${ }^{13}$ A. P. Mathew, K. Oksman, M. Sain, Mechanical properties of biodegradable composites from poly lactic acid (PLA) and microcrystalline cellulose (MCC), Journal of Applied Polymer Science, 97 (2005) 5, 2014-2025, doi:10.1002/app.21779

${ }^{14}$ J. M. Anderson, M. S. Shive, Biodegradation and biocompatibility of PLA and PLGA microspheres, Advanced Drug Delivery Reviews, 28 (1997) 1, 5-24, doi:10.1016/S0169-409X(97)00048-3

${ }^{15}$ W. E. Lorensen, H. E. Cline, Marching cubes: A high resolution 3D surface construction algorithm, ACM SIGGRAPH Computer Graphics, 21 (1987) 1, 163-169

${ }^{16}$ I. Jandejsek, J. Valach, D. Vavrik, Optimization and Calibration of Digital Image Correlation method, Proc. of Experimental Stress Analysis, Olomouc 2010, 121-126

${ }^{17}$ B. D. Lucas, T. Kanade, An iterative image registration technique with an application to stereo vision, Proc. of the 7th International Joint Conference on Artificial Intelligence - Volume 2, San Francisco 1981, 674-679 